\title{
MAGNETIC RESONANCE IMAGING TRACKING OF HUMAN ADIPOSE DERIVED STROMAL CELLS WITHIN THREE-DIMENSIONAL SCAFFOLDS FOR BONE TISSUE ENGINEERING
}

\author{
C. Lalande ${ }^{1,2}$, S. Miraux ${ }^{1,3}$, S.M. Derkaoui ${ }^{4,5}$, S. Mornet ${ }^{6}$, R. Bareille ${ }^{1,2}$, J.C. Fricain ${ }^{1,2}$, J.M. Franconi1 ${ }^{1,3}$, \\ C. Le Visage ${ }^{4,5}$, D. Letourneur ${ }^{4,5}$, J. Amédée ${ }^{1,2}$ and A.K. Bouzier-Sore ${ }^{1,3}$ \\ ${ }^{1}$ Université Bordeaux, Bordeaux F33076, France \\ ${ }^{2}$ INSERM U1026, Tissue Bioengineering, Bordeaux F33076, France \\ ${ }^{3}$ RMSB Centre, UMR 5536, CNRS, 33076 Cedex, France \\ ${ }^{4}$ INSERM, U698, Paris, F-75018, France \\ ${ }^{5}$ Pres Sorbonne Paris Cité, Paris, F-75005, France
}

\begin{abstract}
For bone tissue engineering, human Adipose Derived Stem Cells (hADSCs) are proposed to be associated with a scaffold for promoting bone regeneration. After implantation, cellularised scaffolds require a non-invasive method for monitoring their fate in vivo. The purpose of this study was to use Magnetic Resonance Imaging (MRI)based tracking of these cells, labelled with magnetic agents for in vivo longitudinal assessment. hADSCs were isolated from adipose tissue and labelled with USPIO-rhodamine (Ultrasmall SuperParamagnetic Iron Oxide). USPIO internalisation, absence of toxicity towards hADSCs, and osteogenic differentiation of the labelled cells were evaluated in standard culture conditions. Labelled cells were then seeded within a 3D porous polysaccharidebased scaffold and imaged in vitro using fluorescence microscopy and MRI. Cellularised scaffolds were implanted subcutaneously in nude mice and MRI analyses were performed from 1 to $28 \mathrm{~d}$ after implantation. In vitro, no effect of USPIO labelling on cell viability and osteogenic differentiation was found. USPIO were efficiently internalised by hADSCs and generated a high $\mathrm{T} 2 *$ contrast. In vivo MRI revealed that hADSCs remain detectable until $28 \mathrm{~d}$ after implantation and could migrate from the scaffold and colonise the area around it. These data suggested that this scaffold might behave as a cell carrier capable of both holding a cell fraction and delivering cells to the site of implantation. In addition, the present findings evidenced that MRI is a reliable technique to validate cell-seeding procedures in $3 \mathrm{D}$ porous scaffolds, and to assess the fate of hADSCs transplanted in vivo.
\end{abstract}

Keywords: Bone tissue engineering, adipose derived stromal cells, magnetic resonance imaging, human stem cell magnetic labelling, ultrasmall superparamagnetic iron oxide, 3D porous scaffold.

\footnotetext{
*Address for correspondence:

Charlotte Lalande

Inserm U1026

Université Bordeaux Segalen

F-33076 Bordeaux, France
}

Telephone Number: + 33557571730 .

E-mail: charlotte.lalande@inserm.fr
Introduction

Regeneration of large bone defects represents a major challenge for orthopaedic and reconstructive surgeons. Until recently, the use of autologous bone grafts has been the gold standard method for bone repair (Brown and Cruess, 1982). However, the concept of bone tissue engineering has emerged in response to tissue reconstruction problems involved with autologous bone grafts such as lack of donor, donor site morbidity and immune reaction (De Boer, 1988). The concept consists in developing a hybrid substitute that combines the osteogenic potential of autologous cells with a biocompatible three-dimensional scaffold to generate a new bone tissue that must be structurally and functionally similar to the surrounding bone. Such a scaffold is implanted in a bone defect, remodelled in vivo and results in newly formed tissue (Frohlich et al., 2008).

Human adult mesenchymal stem cells (MSCs) are an interesting cell source of autologous osteogenic cells thanks to their properties of self-renewal and differentiation towards many lineages (adipogenic, osteogenic, chondrogenic, endothelial, neurogenic) and have a clinical potential for tissue engineering (Hodgkinson et al., 2009; Kwan et al., 2008). For bone regeneration, MSCs from bone marrow aspirates are usually used (Pittenger et al., 1999), but account only for $0.001 \%$ to $0.0001 \%$ of total nucleated cells (Fraser et al., 2006). Recently, human Adipose Derived Stem Cells (hADSCs) have been described as an alternative source with easier accessibility, higher abundance and osteogenic differentiation potential (Hattori et al., 2004; Gimble et al., 2007), making them attractive for bone tissue engineering and clinical applications (Dudas et al., 2006; Kakudo et al., 2008).

In the context of tissue engineering, cells must be associated with a biocompatible scaffold able to carry and deliver them in vivo (Logeart-Avramoglou et al., 2005). These scaffolds should create a 3D environment suitable for allowing cell expansion, osteogenic differentiation, extracellular matrix production and, ultimately, supporting tissue reconstruction (Jeon et al., 2008; Leong et al., 2008). Numerous papers describe the efficiency of polymers as scaffolds (Rezwan et al., 2006; Swetha et al., 2010) for bone tissue engineering applications. Among polymers, some natural polysaccharides with biocompatibility, ability to mimic extracellular matrix and trap growth factors, have been tested as scaffolds for transplanted cells 
to promote regeneration of mineralised and vascularised tissues. Here, we used a 3D porous scaffold made of pullulan and dextran polysaccharides (Le Visage, 2009a; Le Visage, 2009b) for bone tissue engineering applications. This biomaterial has already been successfully used in vitro for cardiovascular engineering applications (Autissier et al., 2007; Thebaud et al., 2007; Autissier et al., 2010). Furthermore, its porosity is compatible with the ingrowth of bone tissue (Karageorgiou and Kaplan, 2005) and our preliminary data showed that human ADSCs were able to differentiate into osteogenic cells within these 3D matrices and to express in vitro bone specific markers.

With the promising data from tissue engineering strategies and the potential of these scaffolds for carrying cells, the critical issues are to monitor the engraftment efficiency, temporal and spatial migration of implanted cells, as well as their viability and functional capability in vivo. To track in real-time changes of cell location and the functional status of transplanted cells, non-invasive cell imaging techniques have been introduced. Magnetic Resonance Imaging (MRI) is a method of choice for in vivo longitudinal assessments since it is a non-invasive and non-irradiant technique offering high spatial and temporal resolution (Rogers et al., 2006; Poirier-Quinot et al., 2010). To produce an identifiable change in signal intensity, the cells of interest must be labelled with MR contrast agents (Bulte et al., 2002; Bos et al., 2004; Riviere et al., 2005). These agents cause hydrogen relaxivity changes and create contrast modifications. They include paramagnetic agents or T1 agents mainly based on Gadolinium and superparamagnetic agents or T2 agents based on iron oxide core. Superparamagnetic T2 agents are preferentially used for cellular MRI (Hyafil et al., 2006) since they are more biocompatible than T1 agents. Furthermore, they are highly magnetic, resulting in high contrast modification on MRI with lower concentration than T1 paramagnetic agents. T2-agents based on maghemite cores bonded to dextran and functionalised with poly(ethylene glycol) have been used here (Mornet et al., 2005; Duguet et al., 2006). Compared to the other T2 agents (USPIO, SPIO, MION), they possess covalent bonds between dextran layers that increase their stability and make them an ideal tool for in vivo cell MRI tracking. Furthermore, they possess high relaxivity, and have already been used in another study with microglias in which it was demonstrated that these nanoparticles allow in vitro and in vivo MRI cell tracking (Bouzier-Sore et al., 2010). However, the uptake of these particles could vary largely between different cell types, and some non-phagocytic cells need the combination of particles with transfection agents for efficient cell labelling (Frank et al., 2003; Kustermann et al., 2008).

Regarding mesenchymal stem cells, numerous papers described the high efficiency in labelling bone marrow stromal cells from different sources, while only few data were published with ADSCs, and mainly from animal sources. To our knowledge, no papers describe the use of USPIO for labelling human adipose derived stromal cells and tracking them in a tissue engineered construct. Since our macroporous polysaccharide-based scaffold allowed osteogenic differentiation of hADSCs, we conducted here in vivo studies to examine the cellular behaviour of
hADSCs within this scaffold for developing new bone tissue-engineered constructs.

First, we studied the cytocompatibility of USPIO and their effect on metabolic activity and osteoblastic differentiation capability of labelled hADSCs. We also evaluated in vitro the nuclear magnetic resonance properties of labelled cells. Finally, we performed in vivo MRI cell tracking up to one month after implantation in a subcutaneous site in nude mice of the scaffold loaded with labelled cells. Our results demonstrate that highresolution 4.7-T MRI shows promise for non-invasive 3D visualisation of labelled hADSCs within a macroporous polysaccharide-based scaffold before and after in vivo implantation. In addition, images revealed that transplanted hADSCs could migrate within the scaffold, and could colonise the surrounding area of the scaffold. This suggests that these scaffolds act as carriers and cell delivery structures for tissue regeneration.

\section{Materials and Methods}

\section{Isolation and culture of hADSCs}

hADSCs were isolated and cultured as previously described (Bunnell et al., 2008) with minor modifications. Briefly, human adipose tissue was obtained from patients undergoing liposuction. Tissue samples were minced and digested in a solution of $0.1 \%(\mathrm{w} / \mathrm{v})$ collagenase type I (Worthington, Lakewood, NJ, USA) for $1.5 \mathrm{~h}$ at $37{ }^{\circ} \mathrm{C}$ with vigorous shaking. After filtration and centrifugation, the top lipid layer was removed and the remaining Stromal Vascular Fraction (SVF) was treated for $10 \mathrm{~min}$ with ELB (Erythrocyte Lysis Buffer; $155 \mathrm{mM} \mathrm{NH}_{4} \mathrm{Cl}$ (SigmaAldrich, St. Louis, MO, USA), $5.7 \mathrm{mM} \mathrm{K}{ }_{2} \mathrm{HPO}_{4}, 7.4$ $\mathrm{mM} \mathrm{K} \mathrm{HPO}_{4}-3 \mathrm{H}_{2} \mathrm{O}, 0.1 \mathrm{mM}$ EDTA (all Sigma-Aldrich)) and then centrifuged. The pellet was resuspended in basal medium, DMEM F12 medium (Invitrogen/Life Technologies, Sergy Pontoise, France) supplemented with 10\% (v/v) Foetal Bovine Serum (FBS) (Lonza, Basel, Switzerland) and sequentially filtered through 100, 70 and $40 \mu \mathrm{m}$ cell strainer (BD Falcon, Franklin Lakes, NJ, USA). Cells were plated $\left(10^{4}\right.$ cells $\left./ \mathrm{cm}^{2}\right)$ and cultivated at $37^{\circ} \mathrm{C}$ in $5 \% \mathrm{CO}_{2}$. Culture medium was replaced every three days.

Osteoinductive medium contains IMDM (Invitrogen) supplemented with $10 \%$ (v/v) FBS, $10 \mathrm{mM}$ $\beta$-glycerophophate, $10^{-8} \mathrm{M}$ dexamethasone, and $50 \mu \mathrm{g} / \mathrm{ml}$ ascorbic acid (all Sigma-Aldrich).

\section{Synthesis of USPIO nanoparticles}

USPIO magnetic particles are composed of maghemite cores modified on their surface by aminosilane coupling agents and covalently embedded by a dextran corona. Their surface was functionalised with homo and heterobifunctional poly(ethylene glycol) (PEG) to improve their colloidal stability and stealth. Moreover, they were dye-labelled with a rhodamine derivative (5(6)-carboxy-Xrhodamine $\mathrm{N}$-succinimidyl ester). All the synthesis details have already been reported (Duguet et al., 2006; Mornet et al., 2005). The mean diameter of the maghemite $\left(\gamma-\mathrm{Fe}_{2} \mathrm{O}_{3}\right)$ cores was $7.5 \pm 0.27 \mathrm{~nm}$ as determined by transmission electron microscopy and was increased to a hydrodynamic 
diameter determined by photon correlation spectroscopy of 50-80 nm as dextran and PEG modifications occurred.

\section{Cell labelling and flow cytometric experiments}

Adherent cell cultures (around 80\% confluence) were incubated with USPIO $\left(15 \mathrm{mM} \mathrm{Fe}^{3+}\right)$ associated with protamine sulfate (PS) at $1 \mu \mathrm{g} / \mathrm{mL}$ (USPIO-PS) in a serum-free DMEM F12 medium (Invitrogen). After $24 \mathrm{~h}$ of incubation, cells were washed with PBS $0.1 \mathrm{M}$ pH 7.4 and harvested by trypsinisation for flow cytometric analysis using a FacScan (BD-Bioscience) flow cytometer equipped with an argon laser $(\lambda=488 \mathrm{~nm})$. Labelling of hADSCs with rhodamine-coupled USPIO-PS was checked by conventional fluorescent microscopy (Zeiss, Oberkochen, Germany; Axiovert 25). The percentage of internalised nanoparticles in hADSCs was quantified by flow cytometry according to our previous paper (Bouzier-Sore et al., 2010). Three samples were analysed: USPIO-PS nanoparticles alone, hADSCs alone and hADSCs after USPIO-PS incubation. Nanoparticles were easily distinguished from hADSCs on the dot-plot (SSC versus FSC) since they appeared in two different gates in which distribution and fluorescence intensity were quantified.

\section{Transmission electron microscopy for analysis of nanoparticle uptake}

To assess the uptake and localisation of the nanoparticles in hADSCs, transmission electron microscopy was performed. After washing with Sørensen buffer 0.1M (Pottu-Boumendil, 1989) labelled cells were fixed with glutaraldehyde $25 \%(\mathrm{v} / \mathrm{v})$ and $0.2 \mathrm{M}$ phosphate buffered saline (PBS) $\mathrm{pH} 7.4$ for $2 \mathrm{~h}$ at $4{ }^{\circ} \mathrm{C}$ and rinsed with $0.1 \mathrm{M}$ PBS pH 7.4. Cells were post-fixed with $4 \%$ (v/v) osmium tetroxide in 0.2 M PBS ( $\mathrm{pH} 7.4$ ) for $1.5 \mathrm{~h}$ at room temperature, and then rinsed twice in $0.1 \mathrm{M} \mathrm{PBS}$ (pH 7.4) and once in distilled water. Dehydration was then performed by successive incubations in the following order: alcohol $50^{\circ}, 70^{\circ}, 95^{\circ}$ and $100^{\circ}$ and then embedding in a mix of resin and alcohol $100^{\circ}(1: 1)$ for $2 \mathrm{~h}$ at room temperature and thereafter in pure resin overnight at room temperature. Samples were transferred to a new bath of pure resin for $5 \mathrm{~h}$ at room temperature and included in the resin. Polymerisation occurred at $60^{\circ} \mathrm{C}$ for $48 \mathrm{~h}$. Ultrathin sections (thickness 70-72 $\mathrm{nm}$ ) were produced on an

Table 1: Primer sequences used for Q-PCR. ultramicrotome (Leica, Wetzlar, Germany; Ultracut) using a diamond knife. Sections were stained in uranyl acetate or in ethanol $50^{\circ}$ for $25 \mathrm{~min}$, washed with distilled water, dried, incubated for $8 \mathrm{~min}$ in lead citrate, rinsed and dried. The specimens were imaged using a transmission electron microscope (TEM) (Hitachi, Tokyo, Japan; H7650) with high contrast, saturation filament and an accelerating voltage of $80 \mathrm{kV}$. Digital images were obtained with a camera (Gatan, Pleasanton, CA, USA; Orius 11M pixels).

\section{Assessment of USPIO-PS cytotoxicity and labelled hADSCs metabolic activity}

The biocompatibility of USPIO-PS complexes was investigated by flow cytometry. Different fluorochromes were used to assess the viability of labelled and nonlabelled hADSCs. Cells were incubated with USPIO associated with protamine sulfate for $24 \mathrm{~h}$. Viable cells were determined using propidium iodide (PI, $\lambda_{\text {abs }}=546 \mathrm{~nm}$, $\lambda_{\mathrm{em}}=590 \mathrm{~nm}$, Molecular Probes, Eugene, OR, USA). PI was added to the medium $(3 \mu \mathrm{g} / \mathrm{mL})$ of labelled and unlabelled cells for $10 \mathrm{~min}$ at $37{ }^{\circ} \mathrm{C}$, then cells were harvested by trypsinisation for flow cytometric measurements. Mitochondrial membrane potential was investigated with 3,3' dihexyloxacarbocyanine iodine $\operatorname{DIOC}_{6}(3), \lambda_{\text {ex }}=488$ $\mathrm{nm}, \lambda_{\text {em }}=522 \mathrm{~nm}$, Molecular Probes). Labelled and nonlabelled cells were incubated for $10 \mathrm{~min}$ at $37^{\circ} \mathrm{C}$ in $0.1 \mathrm{M}$ $\mathrm{DIOC}_{6}(3)$ before flow cytometric measurements.

To determine the effect of the cell labelling on metabolic activity, cells were plated at $2 \times 10^{4}$ cells $/ \mathrm{cm}^{2}$ in a 96-well plate and USPIO associated with protamine sulphate were added to the cells for $24 \mathrm{~h}$. Metabolic activity of labelled and unlabelled cells was evaluated using the MTT (3-[4,5-dimethylthiazol-2-yl]-2,5diphenyl tetrazolium bromide) assay (Roche Molecular Biochemicals, Indianapolis, IN, USA) at day 1, 6, 11, 14 and 20 . MTT was added $(1 \mathrm{mg} / \mathrm{ml})$ at $37^{\circ} \mathrm{C}$ for $3 \mathrm{~h}$. Then, cells were washed with PBS and the insoluble formazan salt accumulated inside the cells was solubilised with DMSO and quantified spectrophotometrically at $540 \mathrm{~nm}$.

\section{Quantitative real time polymerase chain reaction (Q-PCR)}

Unlabelled cells were harvested by trypsin-EDTA treatment at day 1 of culture for negative reference. Cells were then

\begin{tabular}{|c|c|c|c|}
\hline Transcript & GenBank & Primers sequences & TM ( $\left.^{\circ} \mathbf{C}\right)$ \\
\hline P0 & $\underline{\mathbf{B C 0 1 5 6 9 0}}$ & $\begin{array}{c}\text { forward 5' ATG CCC AGG GAA GAC AGG GC 3' } \\
\text { reverse 5' CCA TCA GCA CCA CAG CCT TC 3' }\end{array}$ & 65 \\
\hline CBFA1/RUNX2 & $\underline{\mathbf{A H 0 0 5 4 9 8}}$ & $\begin{array}{c}\text { forward 5' TCA CCT TGA CCA TAA CCG TCT 3' } \\
\text { reverse 5' CGG GAC ACC TAC TCT CAT ACT 3' }\end{array}$ & 58 \\
\hline ALKALINE PHOSPHATASE & $\underline{\mathbf{B C 0 2 1 2 8 9}}$ & $\begin{array}{c}\text { forward 5' AGC CCT TCA CTG CCA TCC TGT 3' } \\
\text { reverse 5' ATT CTC TCG TTC ACC GCC CAC 3' }\end{array}$ & 65 \\
\hline TYPE I COLLAGEN & $\underline{\mathbf{N M 0 0 0 0 8 9}}$ & $\begin{array}{c}\text { forward 5' GGA ATG AGG AGA CTG GCA ACC 3' } \\
\text { reverse 5' TCA GCA CCA CCG ATG TCC AAA 3' }\end{array}$ & 65 \\
\hline
\end{tabular}


labelled or not and harvested in the same way after $15 \mathrm{~d}$ of culture in basal or osteoinductive medium. Total RNA was extracted using the Nucleospin ${ }^{\circledR}$ RNA kit (MachereyNagel, Düren, Germany). One $\mu \mathrm{g}$ was used as template for single-strand cDNA synthesis with the Superscript preamplification system (Gibco, Paisley, UK) in a $20 \mu \mathrm{l}$ final volume containing $20 \mathrm{mM}$ Tris- $\mathrm{HCl} \mathrm{pH} 8.4,50 \mathrm{mM}$ $\mathrm{KCl}, 2.5 \mathrm{mM} \mathrm{MgCl}, 0.1 \mathrm{mg} / \mathrm{ml} \mathrm{BSA}, 10 \mathrm{mM}$ DTT, 0.5 $\mathrm{mM}$ of each dATP, dCTP, dGTP, dTTP, $0.5 \mu \mathrm{g}$ oligo(dT), and $200 \mathrm{U}$ of reverse transcriptase. After incubation at 42 ${ }^{\circ} \mathrm{C}$ for $50 \mathrm{~min}$, the reaction was stopped at $70{ }^{\circ} \mathrm{C}$ for 15 min. Five $\mu \mathrm{L}$ of cDNA diluted at a 1:80 ratio were mixed to MESA-green (2X, Fischer Scientific, Pittsburgh, PA, USA) and $10 \mu \mathrm{M}$ each of forward and reverse primers (Table 1) in a $25 \mu \mathrm{L}$ final volume and loaded in a 96-well plate. Amplification was performed using the thermocycler (ICycler, Biorad, Hercules, CA, USA). Data were analysed with the iCycler IQ ${ }^{\mathrm{TM}}$ software and compared by the $\Delta \Delta \mathrm{Ct}$ method. Each Q-PCR was performed in duplicate. Data was normalised to P0 mRNA expression for each condition and was quantified relative to cbfa1/runx2, ALP and type I collagen gene expression of hADSCs after $24 \mathrm{~h}$ of culture standardised to 1 .

\section{Alkaline phosphatase (ALP) assay}

Labelled and unlabelled hADSCs were plated at $2 \mathrm{x}$ $10^{4}$ cells $/ \mathrm{cm}^{2}$ and cultured for $15 \mathrm{~d}$ in an osteoinductive medium, or in basal medium. ALP activity was detected using a diagnostic kit (85L-2, Sigma-Aldrich). Samples were fixed with paraformaldehyde $4 \%(\mathrm{w} / \mathrm{v})$ then stained with alkaline dye (Fast blue RR salt supplemented with Naphtol AS-MX phosphate alkaline solution $0.25 \%$, Sigma-Aldrich) for $30 \mathrm{~min}$. Samples were observed with an optical microscope (Zeiss, Axiovert 25).

Intracellular ALP activity was quantified on cell lysates as described by Ackerman (1962). Cells were harvested with trypsin-EDTA $(0.125 \%(\mathrm{w} / \mathrm{v})-0.0625 \%(\mathrm{v} / \mathrm{w})$, Sigma-Aldrich) then lysed by freezing/thawing steps and by SDS addition (sodium dodecyl sulphate, Biorad) $0.1 \%$ (w/v). Alkaline buffer (Alkaline buffer solution $1.5 \mathrm{M}$, (Sigma-Aldrich) and Triton X100 and p-nitrophenyl phosphate substrate (Sigma-Aldrich)) was added to the sample and incubated at $37{ }^{\circ} \mathrm{C}$ for $30 \mathrm{~min}$. Then, after addition of $0.1 \mathrm{M} \mathrm{NaOH}$ to stop the enzymatic reaction, the absorption at $410 \mathrm{~nm}$ was measured by spectrophotometry. ALP activity levels were normalised to the amount of protein in each sample. The protein quantification was performed according to the BCA (BicinChoninic Acid) protein assay protocol (Thermo Scientific, Fremont, CA, USA) described by Smith et al. (1985). Absorbance was read at $550 \mathrm{~nm}$. ALP activity was expressed as nanomoles of inorganic phosphate $(\mathrm{Pi})$ cleaved in $30 \mathrm{~min}$ per microgram of proteins $(n=3)$.

\section{Von Kossa staining}

Extracellular matrix mineralisation was analysed by Von Kossa staining. After $15 \mathrm{~d}$ of culture in basal or osteoinductive medium, labelled and unlabelled cells were fixed in $4 \%(\mathrm{w} / \mathrm{v})$ paraformaldehyde for $10 \mathrm{~min}$ at room temperature. Fixed cells were then rinsed with distilled water, and incubated with silver nitrate $2.5 \%$ (w/v) for 30 min at room temperature in the dark. Silver nitrate was removed; cells were rinsed with distilled water. Carbonate sodium/formalin solution ( $25 \mathrm{~mL}$ formalin, $5 \mathrm{~g} \mathrm{Na}_{2} \mathrm{CO}_{3}$, $100 \mathrm{~mL}$ distilled water) was added to the cells for $1 \mathrm{~min}$ and cells were rinsed with tap water. Extracellular matrix coloration was observed with an optical microscope.

\section{Preparation of 3D scaffold and hADSCs seeding}

Porous polysaccharide-based scaffolds were prepared using a mixture of pullulan/dextran 75:25. Chemical cross-linking of polysaccharides was carried out with sodium trimetaphosphate (STMP) and pores were created by a patented gas-foaming technique (Le Visage, 2009b). Resulting scaffolds were washed extensively with 0.1 M PBS pH 7.4 and then with distilled water. After a freeze-drying step, porous scaffolds were stored at room temperature until use. Here, scaffolds of $6 \mathrm{~mm}$ diameter, $2 \mathrm{~mm}$ thickness $\left(20 \mathrm{~mm}^{3}\right)$ were used for cell seeding in basal or in osteoinductive medium. For in vitro and in vivo MRI experiments, hADSCs were induced for $15 \mathrm{~d}$ in osteoinductive medium and $5 \times 10^{4}$ or $5 \times 10^{5}$ cells were seeded onto the porous scaffolds.

\section{MRI analyses}

MRI experiments were performed on a $4.7 \mathrm{~T}$ Biospec system (Bruker, Ettlingen, Germany) equipped with a 6 $\mathrm{cm}$ BG6 gradient system capable of $950 \mathrm{mT} / \mathrm{m}$ maximum strength. Measurements were performed with a birdcage resonator (35 $\mathrm{mm}$ diameter and $80 \mathrm{~mm}$ length) tuned to 200.3 MHz.

$5 \times 10^{5}$ labelled or unlabeled cells were collected in PBS $0.1 \mathrm{M}, \mathrm{pH} 7.4$ and spun down. The pellet was trapped in small tubes between two layers of agarose gel $1 \%(\mathrm{w} / \mathrm{v})$ in PBS $0.1 \mathrm{M}, \mathrm{pH} 7.4(n=3)$. T2* measurements were performed at $25^{\circ} \mathrm{C}$ with a multi gradient echo sequence (TR = $500 \mathrm{~ms}$; Interecho-time: $1.0 \mathrm{~ms}$; Number of echo images: 20; Field of view (FOV): 20 x 20 mm; Matrix: 128 x 128; Slice thickness: $1 \mathrm{~mm}$ ). Relaxation data were analysed with home-made software developed on Igor Pro (Wavemetrics, Lake Oswego, OR, USA). For each sample, they were fitted according to a mono-exponential function. MRI analyses were also done with control and labelled cells seeded inside scaffolds $\left(5 \times 10^{4}\right.$ or $5 \times 10^{5}$ cells / disk of $\left.20 \mathrm{~mm}^{3}\right)$ and cultured for $48 \mathrm{~h}$ before experiments $(n=3)$. T2* gradient echo experiments were performed with the following parameters: (TE/TR: 5/42 ms; flip angle: $7^{\circ}$; Bandwidth: 16 Hz/Pixel; FOV: 30 x 35 x 35 mm; Matrix: 256 x 192 x 192; Spatial Resolution: 117 x 182 x $182(\mu \mathrm{m})^{3}$; number of averages: 4 ).

\section{In vivo experiments}

Both the procedure and the animal treatment complied with the Principles of Laboratory Animal Care formulated by the National Society for Medical Research. The studies were carried out in accredited animal facilities at the University of Bordeaux 2, under authorisation $\left(\mathrm{N}^{\circ}: 3300048\right.$ of the Ministère de l'Agriculture, France). Nude mice $(n=4)$ weighing $20 \mathrm{~g}$ (Charles River Laboratories, France) were anaesthetised by isoflurane inhalation ( $1 \%-1.5 \%$ in air), the back was disinfected, a mid vertical incision was made, and tissue-engineered constructs prepared with 
two cell densities $\left(5 \times 10^{4}\right.$ or $5 \times 10^{5}$ hADSCs/scaffold) were introduced subcutaneously, one side with labelled hADSCs-seeded scaffolds and the other side with the unlabelled hADSCs-seeded scaffold. The skin was then sutured (Vicryl 4/0).

In vivo MRI experiments were performed at 1,7 , 14, 21 and $28 \mathrm{~d}$ after scaffold implantation. Mice were anaesthetised with isoflurane (1\%-1.5\% in air) and maintained at a constant respiration rate of $75 \pm 15$ respirations/min. The animals were positioned prone within the magnet with the liver at the centre of the NMR coil. A 3D T2*-weighted TrueFISP (Oppelt, 1986) imaging with alternating RF phase pulse method $(4 \varphi)$ and sum of square reconstruction were used as already described (Vasanawala et al., 2000; Miraux et al., 2009) (TE/TR: 5/10 ms; flip angle: $35^{\circ}$; bandwidth: $203 \mathrm{~Hz}$ /pixel; FOV: 32 x 27.5 x $25 \mathrm{~mm}$; matrix: $256 \mathrm{x} 128$ x 110; spatial resolution: $125 \mathrm{x}$ $215 \times 227(\mathrm{~mm})^{3}$; number of averages: 4 ; total acquisition time: $38 \mathrm{~min})$.

\section{Statistical analysis}

Data are represented as the mean \pm standard deviation resulting from independent experiments. Statistical significance of differences between data from experimental groups was tested using a non-parametric Mann-Whitney test. The level of significance was set at $*: p<0.05$.

\section{Results}

Analysis of USPIO internalisation inside the hADSCs We first tested the ability of hADSCs to internalise USPIO in vitro. hADSCs were incubated for $24 \mathrm{~h}$ with fluorescent USPIO associated with $1 \mu \mathrm{g} / \mathrm{mL}$ of protamine sulphate and the efficiency of internalisation was checked by flow cytometry. Fig. 1a shows an increase in fluorescence when USPIO-PS concentrations increased. We also observed that cell labelling efficiency increased with time since fluorescence intensity was 10-fold higher after $24 \mathrm{~h}$ of incubation compared to $4 \mathrm{~h}$ (data not shown). Fluorescent microscopic images (Fig. 1b, 1c) show a positive labelling of hADSCs after $24 \mathrm{~h}$ of incubation with fluorescent USPIO-PS. Transmission electron microscopic images of labelled cells (Fig. 1d-f) revealed USPIO-PS internalisation by hADSCs, and demonstrated the presence of iron aggregates inside cytoplasmic vesicles (from 0.5 to $1.5 \mu \mathrm{m}$ diameter), typical of nanoparticle endocytosis.

The amount of free nanoparticles remaining in the cellular sample after washing was quantified by flow cytometry. Data indicated that $91.26 \pm 1.82 \%$ of nanoparticles were internalised by hADSCs, while $0.13 \pm$ $0.007 \%$ of the signal after USPIO-PS incubation was due to the remaining free nanoparticles.

\section{USPIO-PS are not cytotoxic for ADSCs}

The influence of labelling on the immediate cell survival and on long-term metabolic activity was determined for labelled cells compared to unlabelled cells (Fig. 2). Using flow cytometric analyses, cellular mortality was checked using propidium iodide (Fig. 2a), and the mitochondrial redox potential was studied by assessing the mitochondrial
DiOC $_{6}$ probe accumulation (Fig. 2b). Three sets of samples were analysed: hADSCs before and after USPIO and USPIO-PS internalisation. There was no difference between these three conditions: neither the cellular viability (Fig. 2a) nor the redox potential (Fig. 2b) were modified, indicating that the USPIO-PS complex internalisation was not toxic for these cells. The metabolic activity of labelled cells was checked by MTT assay for up to $20 \mathrm{~d}$ (Fig. 2c). There was only a slight, but significant, loss of metabolic activity at day 11 and 14 for hADSCs labelled with USPIOPS compared to unlabelled cells.

\section{Osteogenic differentiation of labelled hADSCs}

mRNA levels of bone specific markers (cbfa1/runx2, ALP, type I collagen), quantified after $15 \mathrm{~d}$ of culture in osteoinductive medium, revealed no significant difference between labelled and unlabelled hADSCs (Fig. 3a). After $15 \mathrm{~d}$ of culture of labelled hADSCs in osteoinductive medium, the expression at day 15 relative to day 1 is about 8 fold higher for cbfa1/runx2, 1.5 fold higher for ALP m RNA level and 100 fold higher for type 1 collagen. ALP cytochemical staining (Fig. 3b1-b4) and enzymatic activity quantification (Fig. 3b5) in labelled hADSCs were also assessed. After $15 \mathrm{~d}$ of induction, labelled cells exhibited a similar enzymatic activity to that of unlabelled cells, confirming the results of gene expression (Fig. 3a). In addition, Von Kossa staining (Fig. 3c) reveals at day 15 the presence of black calcium deposits in the extracellular matrices showing that labelled cells with USPIO, kept their ability to mineralise in vitro.

Taken together, these data indicate that labelling with USPIO does not alter the capability of hADSCs to differentiate in vitro toward the osteogenic lineage.

\section{Labelled hADSCs within 3D scaffold and MRI images}

Labelled cells within the macroporous polysaccharidebased scaffold were first imaged by fluorescent microscopy. When the suspension of labelled cells was added to the scaffold, cells immediately colonised the scaffold (Fig. 4a, b), and formed after $8 \mathrm{~h}$ numerous clusters (from 50 to 200 $\mu \mathrm{m}$ diameters) inside the pores (Fig. 4c, d).

In vitro MRI analyses (Fig. 5a) were performed on labelled and unlabelled hADSCs embedded in agarose gels. Labelled cells presented a higher relaxivity compared to the unlabelled ones on MRI T2* measurements, corresponding to a decrease in the $\mathrm{T} 2 *$ value $(35 \pm 6 \mathrm{~ms}$ for unlabelled cells vs $2 \pm 2 \mathrm{~ms}$ for labelled cells). MRI T2* imaging was thereafter performed with labelled and unlabelled hADSCs seeded at two cell densities $\left(5 \times 10^{4}\right.$ or $\left.5 \times 10^{5}\right)$ within the macroporous scaffolds (Fig. 5b). The highest contrast was obtained in 3D scaffolds seeded with $5 \times 10^{5}$ labelled cells compared to the unlabeled ones. A contrast was still visible in scaffold loaded with $5 \times 10^{4}$ labelled cells. Furthermore, images evidenced that with increasing cell density in the scaffold, the signal appeared more widespread.

\section{In vivo MRI after subcutaneous implantation of tissue-engineered constructs in nude mice} Labelled or unlabelled cells were seeded within the scaffolds at the same cell densities than for in vitro MRI 

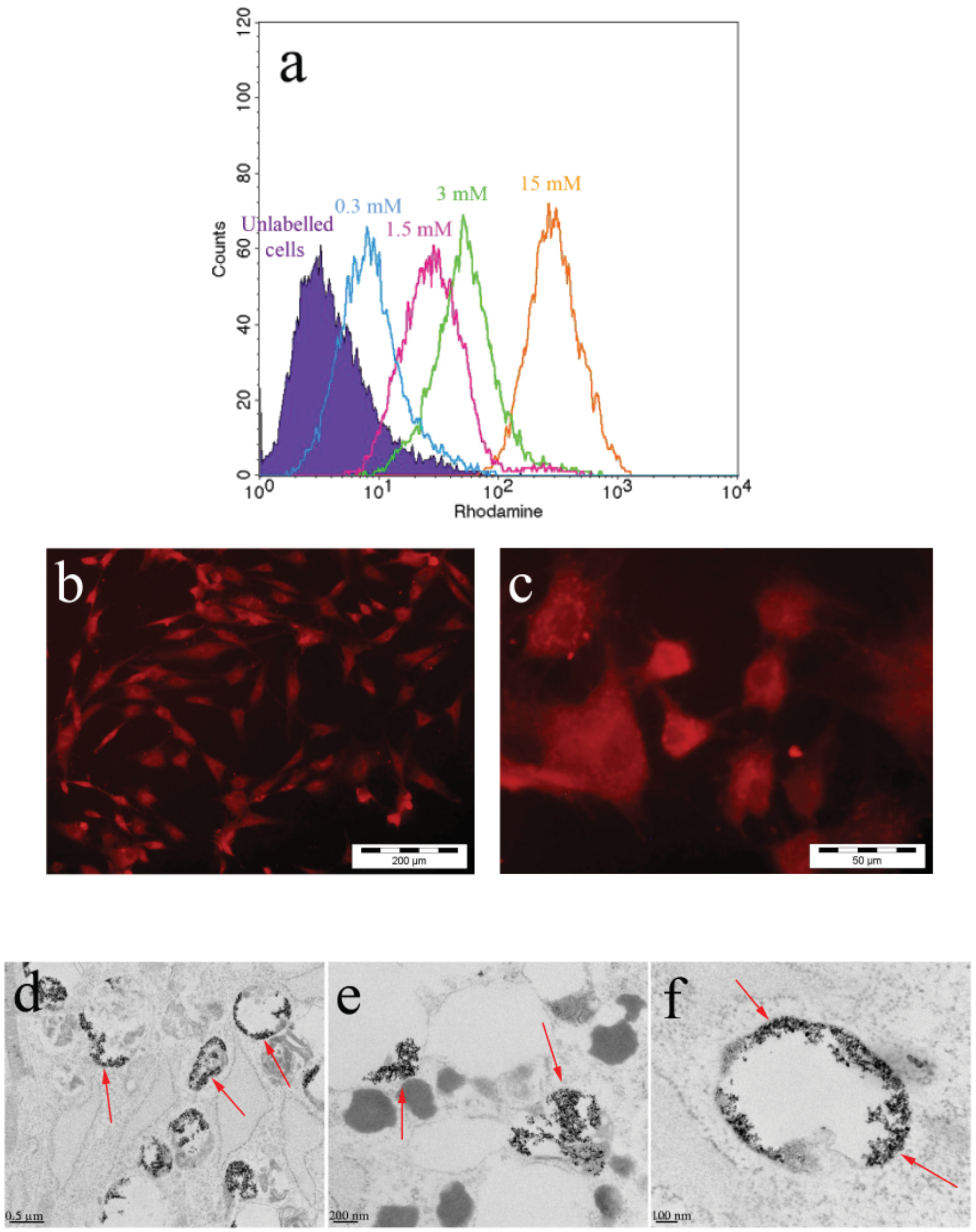

Fig. 1: USPIO internalisation. (a): flow cytometric measurement of fluorescence of hADSCs before and after USPIO-PS labelling with various concentrations of USPIO. (b, c): fluorescent microscopy of labelled hADSCs. (d-f): transmission electron microscopy on labelled hADSCs; arrows indicate USPIO particles, taken up by the cells, inside cytoplasmic vesicles. 

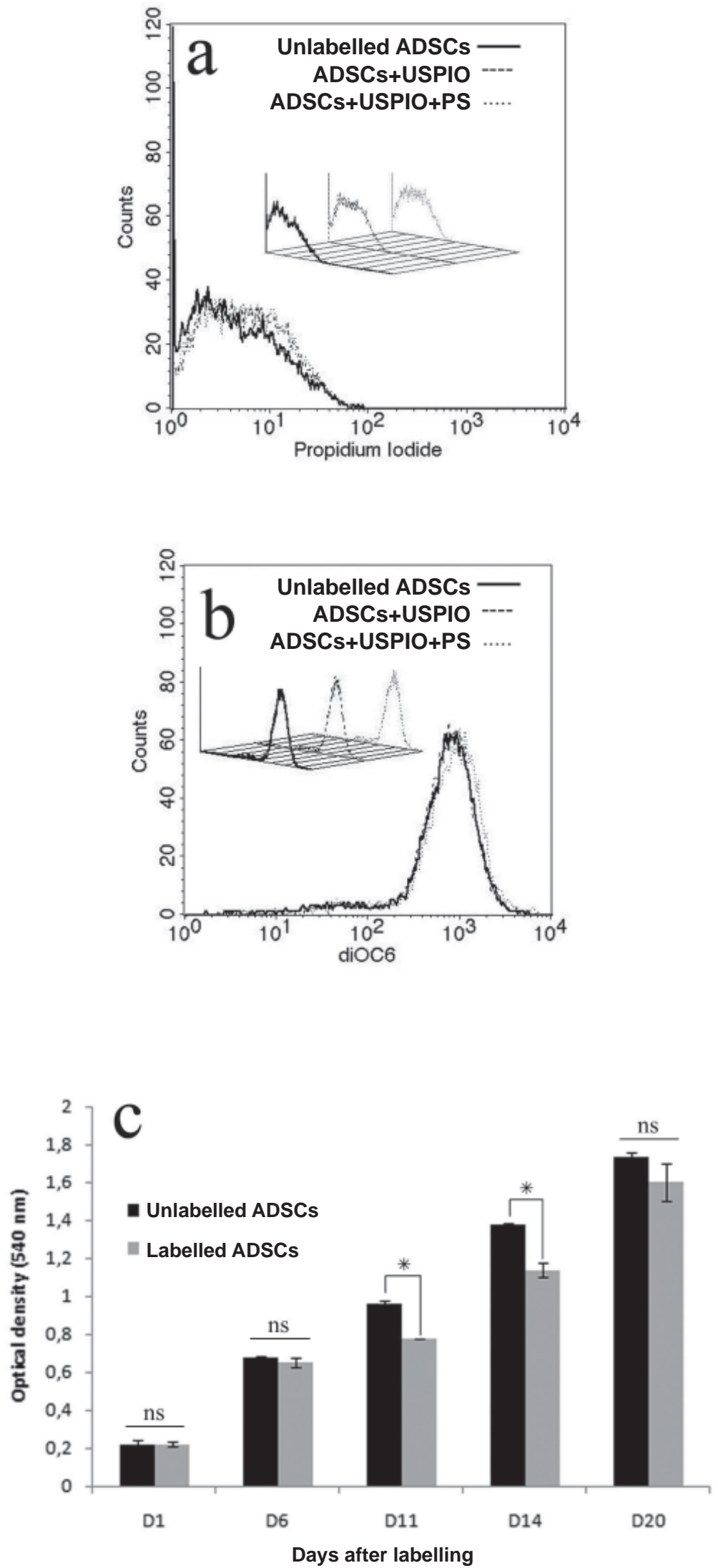

Fig. 2: Assessment of potential USPIO toxicity. (a,b): hADSCs viability was analysed $24 \mathrm{~h}$ after labelling by flow cytometry. Histograms represent the fluorescence of PI (a) and DIOC 6 (b); unlabelled hADSCs (-), hADSCs + USPIO (----), hADSCs + USPIO-PS (....). (c): Metabolic activity of unlabelled and USPIO-PS labelled hADSCs was assessed by MTT assay from day 1 to day 20. A difference between labelled and unlabeled hADSCs was observed at day 11 and day 14. 
a

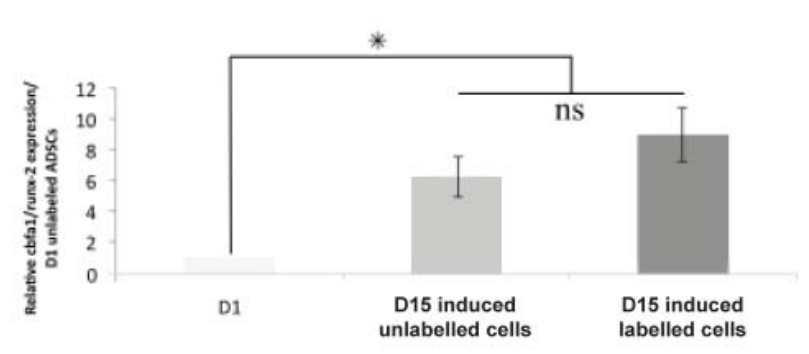

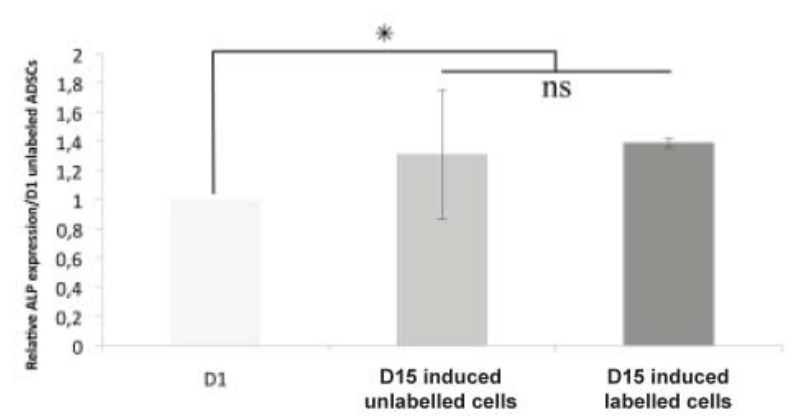

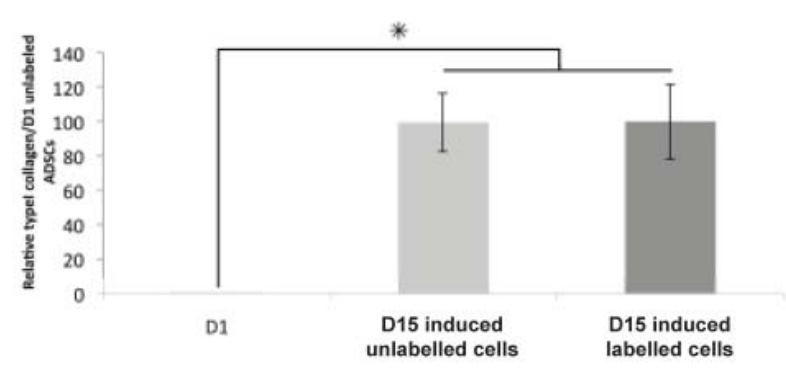

b

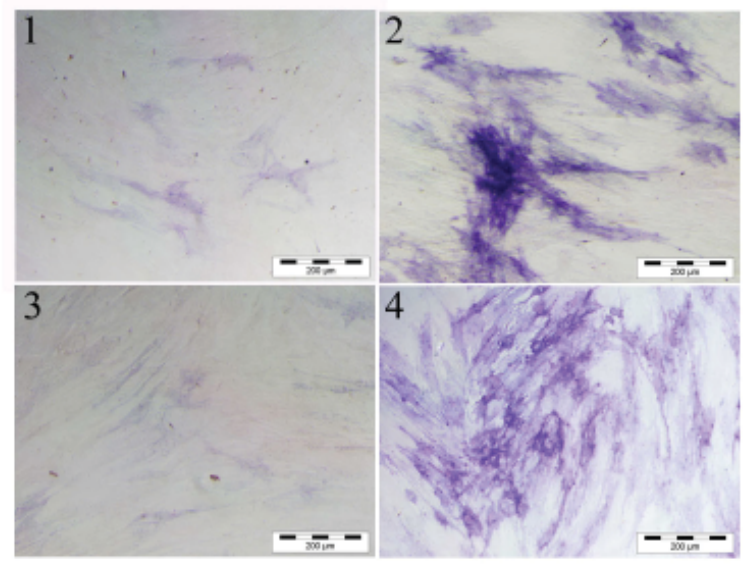

\section{5}

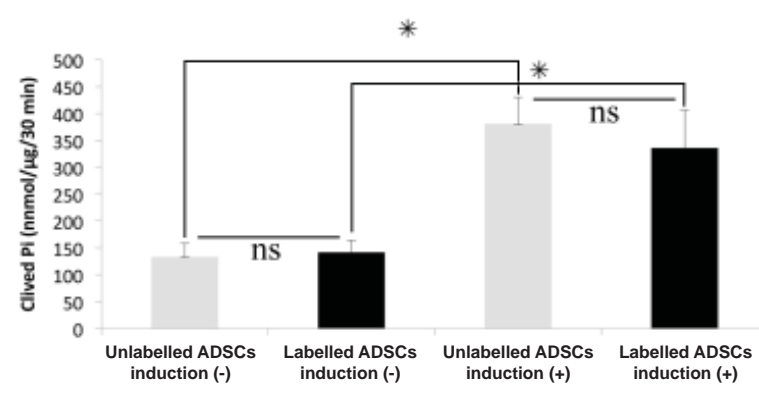

C

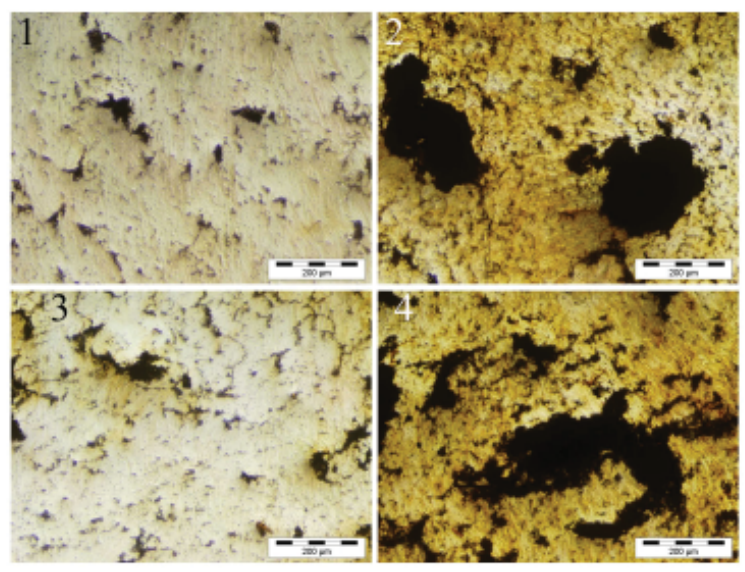

Fig. 3: Osteogenic differentiation capability of cells after USPIO labelling. (a): relative expression of mRNA levels of bone specific markers (cbfa1/runx2, alkaline phosphatase or ALP and type I collagen) in USPIO-labelled and unlabeled ADSCs after $15 \mathrm{~d}$ of induction. (b) ALP cytochemical staining of unlabelled hADSCs (b1, b2) and labelled hADSCs (b3, b4), either non-osteo-induced $(\mathbf{b 1}, \mathbf{b 3})$ or cultured in the osteoinductive medium (b2, b4). ALP quantitative enzymatic activity (b5) was quantified in labelled and unlabelled hADSCs, osteo-induced or not. (c) Von Kossa staining of unlabelled hADSCs (c1, c2) and labelled hADSCs (c3, c4), either non-osteoinduced (c1, c3) or cultured in the osteoinductive medium $(\mathbf{c} 2, \mathbf{c 4})$. 


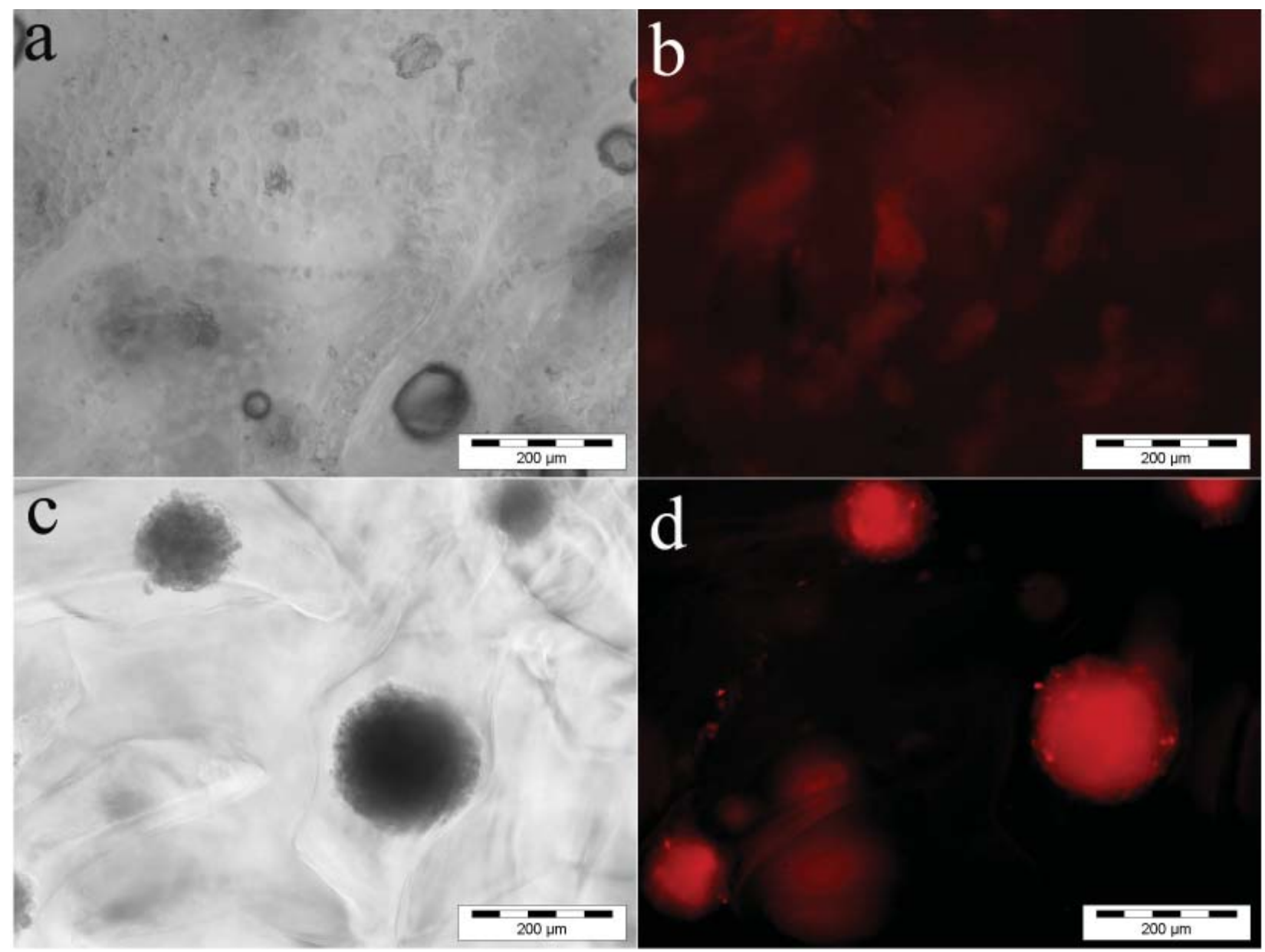

Fig. 4: 3D culture of labelled hADSCs. Optical $(\mathbf{a}, \mathbf{c})$ and fluorescence $(\mathbf{b}, \mathbf{d})$ microscopy of labelled hADSCs seeded into a porous polysaccharide-based scaffold, $1 \mathrm{~h}(\mathbf{a}, \mathbf{b})$ and $8 \mathrm{~h}(\mathbf{c}, \mathbf{d})$ after seeding where cells are organised in clusters inside the pores of the 3D structure. Scale bar: $200 \mu \mathrm{m}$.

\section{Unlabelled cells Labelled cells}
a in agarose gel
$35 \pm 6$
$2 \pm 2$

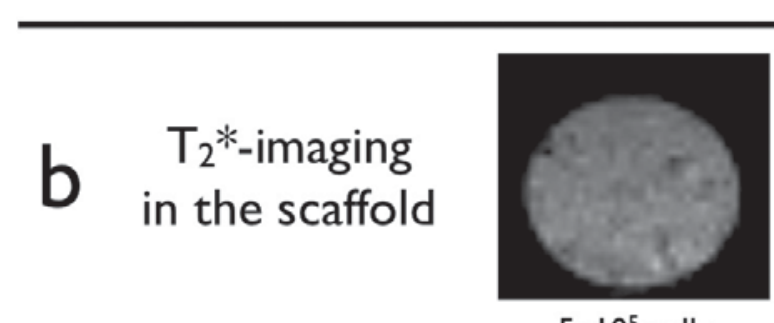

$5 \times 10^{5}$ cells

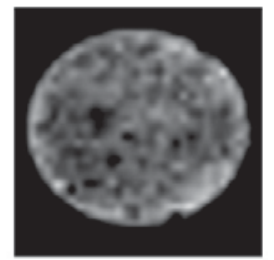

$5 \times 10^{5}$ cells

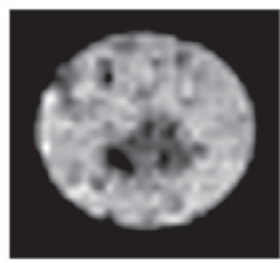

$5 \times 10^{4}$ cells

Fig. 5: In vitro MRI analyses of unlabelled and labelled hADSCs. (a): T2* values obtained for unlabelled and labelled hADSCs in agarose gel $(n=3)$. (b) T2*-imaging obtained for $5 \times 10^{5}$ unlabelled hADSCs and for $5 \times 10^{4}$ and $5 \times 10^{5}$ labelled hADSCs associated to the disk-shaped scaffold $\left(20 \mathrm{~mm}^{3}\right)$. Images were obtained at $4.7 \mathrm{~T}$. 

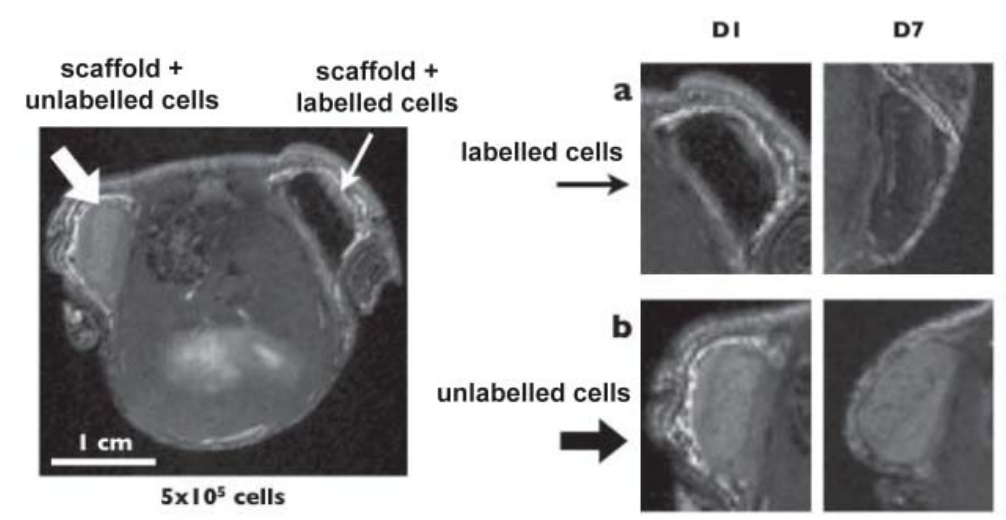

DI4

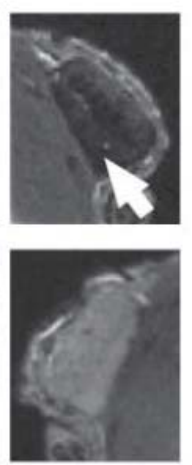

D21

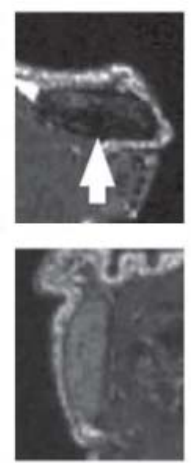

D28
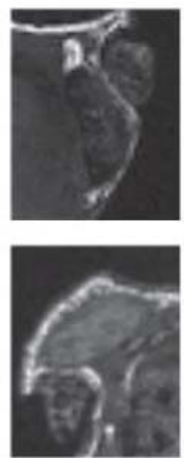

Fig. 6: In vivo MR imaging of scaffolds loaded with $5 \times 10^{5}$ labelled (a) or unlabeled hADSCs (b) per $20 \mathrm{~mm}^{3}$ disk at different times (days 1, 7, 14, 21 and 28) after implantation. On the left, macroscopic MR images obtained at day 1 showing both scaffold loaded with labelled and unlabelled cells seeded with $5 \times 10^{5}$. The arrows indicate the position of the scaffold with labelled (small arrow on the right) and unlabelled cells (large arrow on the right). Images were obtained at $4.7 \mathrm{~T}$ with a $\mathrm{T} 2 *$-gradient echo sequence.

scaffold + unlabelled cells

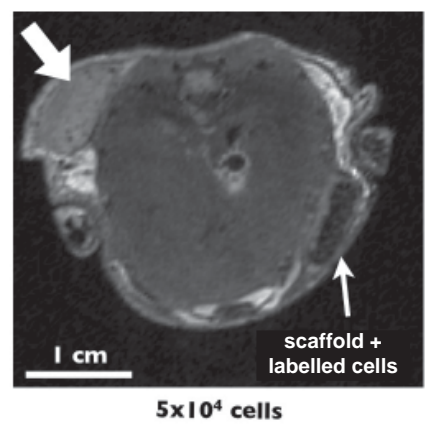

D I
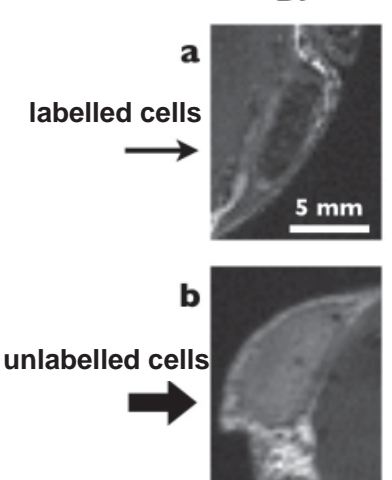

D7
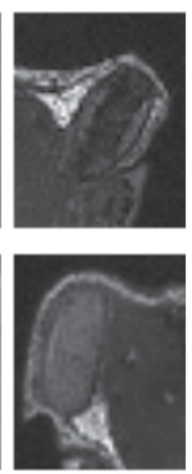

DI4
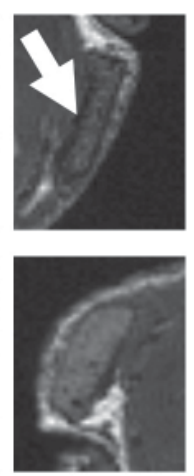

D21
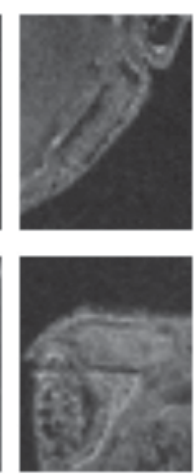

D28
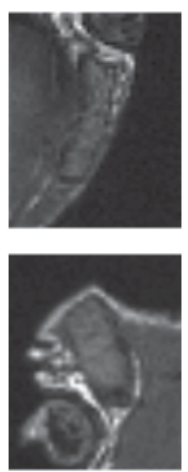

Fig. 7: In vivo MR imaging of scaffolds loaded with $5 \times 10^{4}$ labelled (a) or unlabeled hADSCs (b) per $20 \mathrm{~mm}^{3}$ disk at different times (day 1, 7, 14, 21 and 28) after implantation. On the left, macroscopic MR images obtained at day 1 showing both scaffold loaded with labelled and unlabelled cells seeded with $5 \times 10^{4}$. The arrows indicate the position of the scaffold with labelled (small arrow on the right) and unlabelled cells (large arrow on the right). Images were obtained at $4.7 \mathrm{~T}$ with a $\mathrm{T} 2 *$-gradient echo sequence.

studies $\left(5 \times 10^{4}\right.$ or $\left.5 \times 10^{5}\right)$ and were implanted in nude mice for $28 \mathrm{~d}$ (Fig. 6 and 7). A 3D T2*-weighted TrueFISP MRI experiment was performed at day 1, 7, 14, 21 and 28. Tissue-engineered construct with $5 \times 10^{5}$ labelled cells creates a hyposignal with distinguishing labelled cells (Fig. 6a) from unlabelled cells (Fig. 6b). The signal was still detectable until $28 \mathrm{~d}$ after implantation (Fig. 6b), but decreased with time. Further time points were not investigated.

For the lowest cell density ( $5 \times 10^{4}$ hADSCs/scaffold) (Fig. 7a, b), the signal remains visible during the first two weeks (Fig. 7a) and then seems to locate more at the periphery of the scaffold with time (see arrow). It could suggest that some cells remain in the scaffold, while some other cells could migrate and colonise the area around the matrix (Fig. 7a). This event is clearly observed for the scaffolds cellularised with the two cell densities after 14 $\mathrm{d}$ of implantation (Fig. 6a, 7a; see arrows). Regarding the fate of the scaffold, here seen as a rectangular shape, it was still visible at the same location $28 \mathrm{~d}$ after subcutaneous implantation.

\section{Discussion}

The novelty of this study was to combine the use of i) adipose derived stromal cells from human tissues, ii) an innovative scaffold as a cell carrier and iii) biocompatible superparamagnetic nanoparticles, internalised by hADSCs, to follow their in vivo location by MRI in a non-invasive way, in the context of a new bone tissue engineered construct. Taking together, fluorescence analysis, flow cytometry, TEM and in vitro MRI demonstrated an efficient internalisation of the contrast agents in human mesenchymal stem cells. Moreover, neither the cell viability, nor the osteogenic differentiation capacity of labelled hADSCs was modified. The high relaxivity of USPIO allowed to monitor as few as $5 \times 10^{4}$ labelled hADSCs both in vitro and in vivo by $\mathrm{T} 2 *$-weighted MRI during one month. Interestingly, the location of the signal within the scaffold changes with time of implantation suggesting that some hADSCs were able to migrate to the periphery of the scaffold for participating to tissue regeneration. 
Indeed, MRI is a method of choice to track stem cells in a tissue-engineered construct, because of its excellent spatial resolution, high tissue contrast and lack of ionising radiation. However, magnetic labelling of cells is a prerequisite for their visualisation. Many studies have investigated USPIO-based labelling protocols for monocytes (Oude Engberink et al., 2007), neural stem cells (Politi, 2007) and mesenchymal stem cells (Farrell et al., 2008). Few papers used ADSCs (Rice et al., 2007; Wang et al., 2009) a relevant cell source for bone tissue engineering applications. However, these data were performed on ADSCs arising from animal tissues and revealed that a $24 \mathrm{~h}$ incubation time was required for their labelling (Rice et al., 2007; Wong et al., 2009). In another study (Bouzier-Sore et al., 2010), performed with highly phagocytic microglia cells, a $4 \mathrm{~h}$ incubation was sufficient to obtain a high efficiency for particle internalisation. Therefore, for each cell type, these parameters have to be determined and optimised for monitoring transplanted cells after their implantation. In our study, human ADSCs were efficiently labelled after a $24 \mathrm{~h}$-incubation with USPIO at $15 \mathrm{mM} \mathrm{Fe}^{3+}$ associated with $1 \mu \mathrm{g} / \mathrm{mL}$ PS. The efficiency of USPIO internalisation increased with time but beyond 24 $\mathrm{h}$ of incubation, cell division occurred, inducing labelling dilution. Fluorescence microscopy, TEM observations and flow cytometric analyses confirmed that the nanoparticles preferentially localised in vesicles inside the cytoplasm, either via phagocytosis (Cousin et al., 1999; Villena et al., 2001) or by endocytosis involving or not specific receptors (Raynal et al., 2004).

Several transfection agents can be used to increase cellular nanoparticle uptake (Frank et al., 2003; Arbab et al., 2004). Arbab et al. (2004) used protamine sulfate, a positively charged surfactant, to improve USPIO internalisation. With the addition to USPIO of PS at a noncytotoxic concentration before incubation with hADSCs, we observed homogenisation of the labelled population (data not shown) and a decrease in T2* values after MRI analyses (T2* values: $35 \pm 6 \mathrm{~ms}$ for USPIO-PS compared to $2 \pm 2 \mathrm{~ms}$ for USPIO alone). We hypothesised that after incubation, some nanoparticles attached to the cell membrane (Ribot et al., 2009) could no longer enter the cells. PS might facilitate this internalisation, which does not occur spontaneously. Therefore, we decided to use PS at $1 \mu \mathrm{g} / \mathrm{mL}$ because beyond this concentration there was no longer any beneficial effect, while the toxicity for cells starts at $10 \mu \mathrm{g} / \mathrm{mL}$ (data not shown).

As a first step, we analysed the behaviour of these labelled hADSCs in standard two dimensional cultures. The viability of hADSCs was not modified after labelling, as already demonstrated with USPIO in microglias (Bouzier-Sore et al., 2010). Moreover, the hADSC osteogenic differentiation capacity in vitro was not altered after labelling, and they kept their ability to calcify the extracellular matrix. Mesenchymal stem cells usually maintain their properties of multi-lineage differentiation after magnetic labelling (Arbab et al., 2005), except for one report indicating inhibition of the human chondrogenic differentiation potential (Kostura et al., 2004).

In a bone tissue engineering context, MSCs are associated with a biocompatible scaffold allowing their functionality and the production of a new bone tissue. In this study, we choose to develop a tissue-engineered construct using a natural polymer, a macroporous polysaccharidebased scaffold (Le Visage, 2009a; Le Visage, 2009b). Here, the use of fluorescent USPIO-PS allowed monitoring in vitro the behaviour of labelled hADSCs after seeding within the scaffold. Results showed that cells colonised the scaffold and were organised in clusters in the pores after $8 \mathrm{~h}$ of $3 \mathrm{D}$ culture. We hypothesised that this cluster configuration may favour interactions between cells, thereby promoting osteogenic differentiation (Frohlich et al., 2010) and then production of mineralised matrix, as recently observed with embryonic stem cells (Gothard et al., 2009).

USPIO displayed a high relaxivity that allowed visualising labelled cells in vitro and in vivo by MRI. However, T2* of labelled cells associated within the scaffold could not be measured owing to external parameters related to the scaffold (presence of air bubbles and various water densities within the scaffold). Although a direct quantitative analysis by MRI on the scaffold was not possible, $5 \times 10^{5}$ cells containing nanoparticles were distributed within the entire scaffold and created a high contrast on $\mathrm{T} 2 *$-weighted images. Interestingly, this contrast was still visible for the lowest cell density $(5 \mathrm{x}$ $10^{4}$ ) loaded on the scaffold.

According to these in vitro data, $5 \times 10^{4}$ and $5 \times 10^{5}$ labelled cells were loaded in the scaffolds before the subcutaneous implantation in nude mice. We selected the 3D T2*-weighted TrueFISP method instead of a 3D FLASH gradient echo for in vivo studies. The 3D T2*weighted TrueFISP combines a higher intrinsic contrast and a higher T2* sensitivity (Heyn et al., 2006; MohammadiNejad et al., 2010) compared to classical gradient echo methods. Hence, $5 \times 10^{5}$ labelled cells were detectable for up to $28 \mathrm{~d}$ after implantation. For both cell densities, we observed a loss of signal in the centre of the biomaterial from day 7. Several assumptions are issued from these data. It could be due to cell division of labelled cells, leading to a signal dilution, but it would be surprising to observe this phenomenon only at the centre of the scaffold. It could be also due to cell death in the centre of the biomaterial, leading to nanoparticles release and their diffusion to the periphery of the implant. We could also hypothesise that if cells are suffering in the centre because of hypoxia environment they could migrate at the periphery as happens in vitro. However, if free nanoparticles relocate at the periphery of the implant, we should observe a high increase of the signal, which is not the case. The most probable hypothesis is that labelled cells migrate from the region of implantation and escape from the scaffold and thus could participate to tissue regeneration and implant integration within a bone defect. However, despite the signal loss observed from day 7 , the signal remained detectable in vivo within the scaffold until at least 14 or $28 \mathrm{~d}$ for scaffolds cellularised with $5 \times 10^{4}$ or $5 \times 10^{5}$ of hADSCs, respectively. Then, the scaffold might therefore behave as a cell carrier capable of holding in its own cell fraction and delivering another fraction to the site of implantation for inducing a better tissue regeneration process. This would throw light on their contribution to tissue reconstruction 
and biomaterial integration within the host tissue. Further studies should address the outcome of implanted scaffolds and cells over time. For instance, the fluorescence of the labelled cells could help in determining their distribution and in discriminating host cells from implanted cells. MRI allowed also monitoring the implanted biomaterial and surrounding tissues. Indeed, at no time point we detected a change on the location of the biomaterial, degradation or an inflammatory reaction at the site of implantation.

In conclusion, we have established conditions for labelling hADSCs with USPIO nanoparticles without affecting metabolic activity and osteogenic differentiation capacity. Furthermore, the present findings show that labelled hADSCs within a 3D scaffold can be monitored in vivo by MRI for at least $28 \mathrm{~d}$. In the near future, MRIbased cell tracking could be used for in vivo longitudinal assessment of bone tissue engineered constructs, although MRI should be combined with other methods, like microcomputer tomography (micro-CT) and histomorphometry, to evaluate the capability of this new tissue-engineered construct to generate mineralised bone tissue.

\section{Acknowledgements}

This work was supported by Inserm, University Bordeaux Segalen, Universities Paris 7 and 13, "Délégation Générale de l'Armement" (DGA), and by grants from the French National Research Agency (ANR-07-TecSan-011-01 ITOV; ANR-09-EBIO-001 3D Cell). Thanks to ICELLTIS (Toulouse, France) for providing human adipose derived stromal cells, ABCELLBIO (France) for providing cell culture medium and S. Lacomme (BIC University Bordeaux 2, France) for TEM analyses. Thanks to Patrick Guitton for technical support and to R. Cooke for English improvements.

\section{References}

Ackerman GA (1962) Substituted naphthol as phosphate derivatives for the localization of leukocyte alkaline phosphatase activity. Lab Invest 11: 563-567.

Arbab AS, Yocum GT, Kalish H, Jordan EK, Anderson SA, Khakoo AY, Read EJ, Frank JA (2004) Efficient magnetic cell labeling with protamine sulfate complexed to ferumoxides for cellular MRI. Blood 104: 1217-1223.

Arbab AS, Yocum GT, Rad AM, Khakoo AY, Fellowes V, Read EJ, Frank JA (2005) Labeling of cells with ferumoxides-protamine sulfate complexes does not inhibit function or differentiation capacity of hematopoietic or mesenchymal stem cells. NMR Biomed 18: 553-559.

Autissier A, Letourneur D, Le Visage C (2007) Pullulan-based hydrogel for smooth muscle cell culture. J Biomed Mater Res A 82: 336-342.

Autissier A, Visage CL, Pouzet C, Chaubet F, Letourneur D (2010) Fabrication of porous polysaccharidebased scaffolds using a combined freeze-drying/crossLinking process. Acta Biomater 6: 3640-3648.
Bos C, Delmas Y, Desmouliere A, Solanilla A, Hauger O, Grosset C, Dubus I, Ivanovic Z, Rosenbaum J, Charbord P, Combe C, Bulte JW, Moonen CT, Ripoche J, Grenier $\mathrm{N}$ (2004) In vivo MR imaging of intravascularly injected magnetically labeled mesenchymal stem cells in rat kidney and liver. Radiology 233: 781-789.

Bouzier-Sore AK, Ribot E, Bouchaud V, Miraux S, Duguet E, Mornet S, Clofent-Sanchez G, Franconi JM, Voisin P (2010) Nanoparticle phagocytosis and cellular stress: involvement in cellular imaging and in gene therapy against glioma. NMR Biomed 23: 88-96.

Brown KL, Cruess RL (1982) Bone and cartilage transplantation in orthopaedic surgery. A review. J Bone Joint Surg Am 64: 270-279.

Bulte JW, Duncan ID, Frank JA (2002) In vivo magnetic resonance tracking of magnetically labeled cells after transplantation. J Cereb Blood Flow Metab 22: 899-907.

Bunnell BA, Flaat M, Gagliardi C, Patel B, Ripoll C (2008) Adipose-derived stem cells: Isolation, expansion and differentiation. Methods 45: 115-120.

Cousin B, Munoz O, Andre M, Fontanilles AM, Dani C, Cousin JL, Laharrague P, Casteilla L, Penicaud L (1999) A role for preadipocytes as macrophage-like cells. FASEB J 13: 305-312.

De Boer HH (1988) The history of bone grafts. Clin Orthop Relat Res 226: 292-298.

Dudas JR, Marra KG, Cooper GM, Penascino VM, Mooney MP, Jiang S, Rubin JP, Losee JE (2006) The osteogenic potential of adipose-derived stem cells for the repair of rabbit calvarial defects. Ann Plast Surg 56: 543548.

Duguet E, Vasseur S, Mornet S, Devoisselle JM (2006) Magnetic nanoparticles and their applications in medicine. Nanomedicine (Lond) 1: 157-168.

Farrell E, Wielopolski P, Pavljasevic P, van Tiel S, Jahr H, Verhaar J, Weinans H, Krestin G, O'Brien FJ, van Osch G, Bernsen M (2008) Effects of iron oxide incorporation for long term cell tracking on MSC differentiation in vitro and in vivo. Biochem Biophys Res Commun 369: 1076-1081.

Frank JA, Miller BR, Arbab AS, Zywicke HA, Jordan EK, Lewis BK, Bryant LH, Jr., Bulte JW (2003) Clinically applicable labeling of mammalian and stem cells by combining superparamagnetic iron oxides and transfection agents. Radiology 228: 480-487.

Fraser JK, Wulur I, Alfonso Z, Hedrick MH (2006) Fat tissue: An underappreciated source of stem cells for biotechnology. Trends Biotechnol 24: 150-154.

Frohlich M, Grayson WL, Wan LQ, Marolt D, Drobnic M, Vunjak-Novakovic G (2008) Tissue engineered bone grafts: Biological requirements, tissue culture and clinical relevance. Curr Stem Cell Res Ther 3: 254-264.

Frohlich M, Grayson WL, Marolt D, Gimble JM, Kregar-Velikonja N, Vunjak-Novakovic G (2010) Bone grafts engineered from human adipose-derived stem cells in perfusion bioreactor culture. Tissue Eng Part A 16: 179189.

Gimble JM, Katz AJ, Bunnell BA (2007) Adiposederived stem cells for regenerative medicine. Circ Res 100: $1249-1260$. 
Gothard D, Roberts SJ, Shakesheff K, Buttery LD (2009) Engineering embryonic stem cell aggregation allows an enhanced osteogenic differentiation in vitro. Tissue Eng Part C Meth 16: 583-595.

Hattori H, Sato M, Masuoka K, Ishihara M, Kikuchi T, Matsui T, Takase B, Ishizuka T, Kikuchi M, Fujikawa K, Ishihara M (2004) Osteogenic potential of human adipose tissue-derived stromal cells as an alternative stem cell source. Cells Tissues Organs 178: 2-12.

Heyn C, Ronald JA, Mackenzie LT, MacDonald IC, Chambers AF, Rutt BK, Foster PJ (2006) In vivo magnetic resonance imaging of single cells in mouse brain with optical validation. Magn Reson Med 55: 23-29.

Hodgkinson T, Yuan XF, Bayat A (2009) Adult stem cells in tissue engineering. Expert Rev Med Devices 6: 621-640.

Hyafil F, Laissy JP, Mazighi M, Tchetche D, Louedec L, Adle-Biassette H, Chillon S, Henin D, Jacob MP, Letourneur D, Feldman LJ (2006) Ferumoxtran-10enhanced MRI of the hypercholesterolemic rabbit aorta: Relationship between signal loss and macrophage infiltration. Arterioscler Thromb Vasc Biol 26: 176-181.

Jeon O, Rhie JW, Kwon IK, Kim JH, Kim BS, Lee SH (2008) In vivo bone formation following transplantation of human adipose-derived stromal cells that are not differentiated osteogenically. Tissue Eng Part A 14: 1285 1294.

Kakudo N, Shimotsuma A, Miyake S, Kushida S, Kusumoto K (2008) Bone tissue engineering using human adipose-derived stem cells and honeycomb collagen scaffold. J Biomed Mater Res A 84: 191-197.

Karageorgiou V, Kaplan D (2005) Porosity of 3D biomaterial scaffolds and osteogenesis. Biomaterials 26: 5474-5491.

Kostura L, Kraitchman DL, Mackay AM, Pittenger MF, Bulte JW (2004) Feridex labeling of mesenchymal stem cells inhibits chondrogenesis but not adipogenesis or osteogenesis. NMR Biomed 17: 513-517.

Kustermann E, Himmelreich U, Kandal K, Geelen T, Ketkar A, Wiedermann D, Strecker C, Esser J, Arnhold S, Hoehn M (2008) Efficient stem cell labeling for MRI studies. Contrast Media Mol Imaging 3: 27-37.

Kwan MD, Slater BJ, Wan DC, Longaker MT (2008) Cell-based therapies for skeletal regenerative medicine. Hum Mol Genet 17: R93-98.

Le Visage C, Chaubet F, Autissier A, Letourneur D (2009a) Method for preparing porous scaffold for tissue engineering. Patent WO2009/047346.

Le Visage C, Letourneur D (2009b) Method for preparing porous scaffold for tissue engineering, Cell culture and cell delivery. Patent WO2009/047347.

Leong DT, Nah WK, Gupta A, Hutmacher DW, Woodruff MA (2008) The osteogenic differentiation of adipose tissue-derived precursor cells in a 3D scaffold/ matrix environment. Curr Drug Discov Technol 5: 319-327.

Logeart-Avramoglou D, Anagnostou F, Bizios R, Petite H (2005) Engineering bone: Challenges and obstacles. J Cell Mol Med 9: 72-84.

Miraux S, Calmettes G, Massot P, Lefrancois W, Parzy E, Muller B, Arsac LM, Deschodt-Arsac V, Franconi JM,
Diolez P, Thiaudiere E (2009) 4D Retrospective black blood Truefisp imaging of mouse heart. Magn Reson Med 62: 1099-1105.

Mohammadi-Nejad AR, Hossein-Zadeh GA, SoltanianZadeh H (2010) Quantitative evaluation of optimal imaging parameters for single-cell detection in MRI using simulation. Magn Reson Imaging 28: 408-417.

Mornet S, Portier J, Duguet E (2005) A method for synthesis and functionalization of ultrasmall superparamagnetic covalent carriers based on maghemite and dextran. J Magnetism Magnetic Mater 293: 127-134.

Oppelt A, R. Graumann, H. Barfu, H. Fischer, W. Hartl, W. Schajor (1986) FISP:A new fast MRI sequence. Electromedica 54: 5-18.

Oude Engberink RD, van der Pol SM, Dopp EA, de Vries HE, Blezer EL (2007) Comparison of SPIO and USPIO for in vitro labeling of human monocytes: MR detection and cell function. Radiology 243: 467-474.

Pittenger MF, Mackay AM, Beck SC, Jaiswal RK, Douglas R, Mosca JD, Moorman MA, Simonetti DW, Craig S, Marshak DR (1999) Multilineage potential of adult human mesenchymal stem cells. Science 284: 143-147.

Poirier-Quinot M, Frasca G, Wilhelm C, Luciani N, Ginefri JC, Darrasse L, Letourneur D, Le Visage C, Gazeau F (2010) High-resolution 1.5-Tesla magnetic resonance imaging for tissue-engineered constructs: A noninvasive tool to assess three-dimensional scaffold architecture and cell seeding. Tissue Eng Part C Meth 16: 185-200.

Politi LS (2007) MR-based imaging of neural stem cells. Neuroradiology 49: 523-534.

Pottu-Boumendil J (1989) Microscopie electronique, principes et méthodes de préparation (Electron microscopy: principles and preparative methods). Éditions INSERM, Paris.

Raynal I, Prigent P, Peyramaure S, Najid A, Rebuzzi C, Corot C (2004) Macrophage endocytosis ofsuperparamagnetic iron oxide nanoparticles: Mechanisms and comparison of ferumoxides and ferumoxtran-10. Invest Radiol 39: 56-63.

Rezwan K, Chen QZ, Blaker JJ, Boccaccini AR (2006) Biodegradable and bioactive porous polymer/ inorganic composite scaffolds for bone tissue engineering. Biomaterials 27: 3413-3431.

Ribot EJ, Miraux S, Delville MH, Bouchaud V, Lacomme S, Gontier E, Bouzier-Sore AK, Franconi JM, Thiaudiere E, Voisin P (2009) Study of the MR relaxation of microglia cells labeled with Gd-DTPA-bearing nanoparticles. Contrast Media Mol Imaging 4: 109-117.

Rice HE, Hsu EW, Sheng H, Evenson DA, Freemerman AJ, Safford KM, Provenzale JM, Warner DS, Johnson GA (2007) Superparamagnetic iron oxide labeling and transplantation of adipose-derived stem cells in middle cerebral artery occlusion-injured mice. AJR Am J Roentgenol 188: 1101-1108.

Riviere C, Boudghene FP, Gazeau F, Roger J, Pons JN, Laissy JP, Allaire E, Michel JB, Letourneur D, Deux JF (2005) Iron oxide nanoparticle-labeled rat smooth muscle cells: Cardiac MR imaging for cell graft monitoring and quantitation. Radiology 235: 959-967. 
Rogers WJ, Meyer CH, Kramer CM (2006) Technology insight: In vivo cell tracking by use of MRI. Nat Clin Pract Cardiovasc Med 3: 554-562.

Smith PK, Krohn RI, Hermanson GT, Mallia AK, Gartner FH, Provenzano MD, Fujimoto EK, Goeke NM, Olson BJ, Klenk DC (1985) Measurement of protein using bicinchoninic acid. Anal Biochem 150: 76-85.

Swetha M, Sahithi K, Moorthi A, Srinivasan N, Ramasamy K, Selvamurugan N (2010) Biocomposites containing natural polymers and hydroxyapatite for bone tissue engineering. Int J Biol Macromol 47: 1-4.

Thebaud NB, Pierron D, Bareille R, Le Visage C, Letourneur D, Bordenave L (2007) Human endothelial progenitor cell attachment to polysaccharide-based hydrogels: A pre-requisite for vascular tissue engineering. J Mater Sci Mater Med 18: 339-345.

Vasanawala SS, Pauly JM, Nishimura DG (2000) Linear combination steady-state free $\mathrm{p}$ recession MRI. Magn Reson Med 43: 82-90.

Villena JA, Cousin B, Penicaud L, Casteilla L (2001) Adipose tissues display differential phagocytic and microbicidal activities depending on their localization. Int J Obes Relat Metab Disord 25: 1275-1280.

Wang L, Deng J, Tian W, Xiang B, Yang T, Li G, Wang J, Gruwel M, Kashour T, Rendell J, Glogowski M, Tomanek B, Freed D, Deslauriers R, Arora RC, Tian G (2009) Adipose-derived stem cells are an effective cell candidate for treatment of heart failure: An MR Imaging study of rat hearts. Am J Physiol Heart Circ Physiol 297: H1020-1031.

Wong S, Steinbach L, Zhao J, Stehling C, Ma CB, Link TM (2009) Comparative study of imaging at 3.0 T versus 1.5 T of the knee. Skeletal Radiol 38: 761-769.

\section{Discussion with Reviewer}

Reviewer II: Generally speaking, in imaging we much prefer to have a positive signal (hypersignal) as opposed to a negative one (hyposignal). Though ferromagnetic contrast agents give a negative signal instead of the positive signal we get from a Gd based contrast agent, the ferromagnetic particles can be detected at a much smaller concentration, which is good for the type of work performed here. Please comment.

Authors: A positive signal is always better in MRI in term of image quality and interpretation. Nevertheless, until today, labelled cells with a positive signal appear very challenging. Despite many efforts of different groups, with the use of Gd-nanoparticles, or Manganese-nanoparticles for example, it is not possible to achieve images with the same sensitivity (as USPIO and T2* imaging) and with a positive contrast. This is the reason why ferromagnetic particles have been chosen for cell tracking in this study.

Reviewer II: For an eventual human application, the acquisition sequences are standard and the tracking could be performed by any clinical MRI, though the sensitivity would be better when using those at higher field. Please comment.

Authors: Of course, sensitivity to iron oxide nanoparticles is enhanced at higher field strength. Nevertheless, the sequences used here are standard (gradient echo and TrueFISP) and their acquisition parameters can be easily modified (increase echo time from 5 to 20 or $50 \mathrm{~ms}$ for example) to be very sensitive at clinical field strength (1.5 T or $3 \mathrm{~T}$ ). 